\title{
Pelatihan dan Pendampingan Tutor Adik Dosen
}

\author{
Stella Prancisca*1, Ikhsanudin², Ana Fergina ${ }^{3}$, Muhammad Ainur Rizqi ${ }^{4}$ \\ 1,2,3 Fakultas Keguruan dan Ilmu Pendidikan, Universitas Tanjungpura \\ 1,3,4UPT Bahasa, Universitas Tanjungpura \\ *e-mail: stellaguru123@gmail.com ${ }^{1}$, ikhsan.edu@gmail.com ${ }^{2}$, anafergina@gmail.com ${ }^{3}$, \\ ainurrizqi89@gmail.com ${ }^{4}$
}

\begin{abstract}
Covid-19 outbreak pushed the educational system to shift from in person to online learning. Although scholars agree that technology brings multiple benefits for students, this sudden change makes the shift hampered. For example, teachers have difficulty in delivering practical-based materials. In addition, parents complain that they have no time to accompany their children and they do not master materials that their children study. To respond to the second complain, Untan Language Center conducted a community service (PKM) offering a program that provided 17 tutors to help children study from home. To ensure the tutor's quality, they must attend training and internship given by the PKM team. The training was delivered for 1 week, followed by an intership session for 1 month. During the internship, the tutors observed and practiced managing online classrooms. These session are expected to help the tutors anticipate possible problems that might emerge during the online clasroom.
\end{abstract}

Keywords: Online Learning, Covid-19, Study from Home

\begin{abstract}
Abstrak
Wabah COVID-19 memaksa sistem pendidikan beradaptasi menuju pelaksanaan kelas secara daring. Meskipun para peneliti sepakat bahwa adanya teknologi membawa beragam manfaat untuk siswa, perpindahan yang dilakukan secara mendadak ini bukan tanpa hambatan, misalnya kesulitan menyampaikan materi berbasis praktikum dan keluhan orang tua ketika mendampingi anak-anak belajar secara daring. Khusus keluhan kedua, alasan mereka adalah kurangnya waktu karena kesibukan dan kurangnya penguasan materi yang dipelajari oleh anak mereka. Oleh sebab itu, tim PKM UPT Bahasa Untan menawarkan sebuah program yang menyediakan 17 tutor pendamping anak-anak belajar dari rumah. Untuk menjamin kualitas para tutor ini, mereka terlebih dahulu mengikuti pelatihan dan magang yang diberikan oleh dosen pelaksana PKM. Pelatihan ini berbentuk seminar selama 1 minggu yang dilanjutkan dengan pendampingan sesi magang selama 1 bulan. Pada sesi magang, para tutor dilatih untuk mengamati dan mengajar kelas daring. Kedua sesi ini diharapkan dapat membantu mereka mengantisipasi kemungkinan permasalahan yang muncul selama pelaksanaan kelas daring.
\end{abstract}

Kata kunci: Pembelajaran Daring, Covid-19, Belajar dari Rumah

\section{PENDAHULUAN}

Persaingan global yang semakin ketat menuntut setiap bangsa dan negara untuk terus berinovasi dan meningkatkan kualitas bangsanya. Demikian pula yang terjadi di dunia pendidikan Indonesia. Pemerintah sejauh ini terus melakukan upaya perbaikan dan peningkatan mutu sistem pendidikan dan sumber daya manusia yang terlibat di dalamnya. Berkaitan dengan peningkatan kualitas sumber daya manusia di dunia pendidikan Indonesia, begitu banyak hal yang masih perlu dievaluasi, diperbaiki, dan ditingkatkan demi terwujudnya pendidikan yang berkualitas tinggi.

Merebaknya wabah COVID-19 di seluruh dunia sejak awal 2020 semakin memaksa sistem pendidikan berbenah dan beradapatasi. Seperti diketahui, penyebaran wabah Covid-19 yang begitu cepat memaksa hampir semua sektor untuk mengalihkan aktifitasnya pada mode online. Tidak terkecuali sektor pendidikan yang dianggap rentan sebagai tempat penyebaran virus karena hakikat pembelajaran di kelas yang bersifat berkerumun dan melibatkan interaksi sosial antara guru dan siswa maupun antar sesama siswa. Oleh sebab itu, para pendidik harus bisa beradaptasi menuju pelaksanaan kelas secara daring (online), meskipun adaptasi massal ini merupakan sesuatu yang belum pernah terjadi di masa-masa sebelumnya (Sun, Tang, \& Zuo, 2020). Perubahan serempak yang dianalogikan seperti gelombang tsunami ini bertujuan untuk 
membatasi mobilitas masyarakat dan memastikan semua pendidik dan peserta didik berada dalam keadaan sehat. Dengan cepatnya penularan virus ini, penutupan sekolah dan perpindahan moda pembelajaran ke dunia online diyakini sebagai solusi yang paling memungkinkan untuk dilakukan (Herliandry, Nurhasanah, Suban, \& Kuswanto, 2020). Bagi Dhawan, (2020) model pembelajaran yang menggunakan peralatan elektronik yang terhubung dengan internet (online learning) ini bukan lagi merupakan sebuah pilihan, namun sudah menjadi kewajiban.

Para peneliti sudah lama sepakat bahwa adanya teknologi dan dunia online membawa beragam manfaat untuk pembelajaran siswa. Herliandry, Nurhasanah, Suban, and Kuswanto (2020) misalnya, berpendapat bahwa pembelajaran secara online mendorong peserta didik untuk menjadi lebih mandiri. Mereka lebih banyak terlibat dalam pembelaran mereka sendiri mulai dari membaca materi, menyaksikan video pembelajaran, dan sebagainya. Selain itu, model pembelajaran seperti ini dapat mengurangi biaya perjalanan fisik dan memberikan kemudahan untuk mengakses bahan belajar dimana saja tanpa terhalangi jarak dan waktu (Mukhtar, Javed, Arooj, \& Sethi, 2020).

Meskipun demikian, perpindahan yang dilakukan secara mendadak ini bukan tanpa hambatan. Satu yang paling menonjol adalah kesulitan pengajar dalam menyampaikan materi yang berbasis praktikum (Mukhtar, Javed, Arooj, \& Sethi, 2020). Akibatnya, apa yang diterima siswa melalui perangkat online hanya dapat dinilai secara aspek pengetahuan saja (knowledge component). Tentu, hal ini akan menyulitkan bagi beberapa mata pelajaran yang membutuhkan sesi praktikum seperti Bahasa Inggris dan Fisika.

Selain itu, beberapa penitian melaporkan keluhan orang tua ketika mendampingi anakanaknya belajar secara online. Rahmania, Wijayanti, dan Hakim (2020) menyebutkan bahwa kesibukan orang tua dalam bekerja membuat mereka tidak begitu optimal dalam mendampingi anak-anak mereka dalam belajar secara daring. Selain itu, meskipun ada beberapa orang tua yang tidak bekerja, mereka merasa tidak kapabel dalam mendampingi anak-anak mereka. Kadang-kadang mereka juga merasa khawatir anak mereka akan bosan karena mereka tidak bisa menciptakan suasana yang kreatif. Akibatnya, mereka menyerahkan tanggung jawab ini kepada orang lain, seperti kerabat, yang sebenarnya juga tidak memiliki latar belakang pendidikan yang lebih baik dari mereka. Padahal, Rahmania, Wijayanti, dan Hakim (2020) menegaskan bahwa orang tua seharusnya berperan sebagai jembatan yang menghubungkan guru dan siswa sehingga siswa tetap mendapatkan hak-hak mereka dalam belajar. Oleh sebab itu, individu yang mendampingi anak-anak dalam belajar daring ini seharusnya orang-orang yang profesional; yang menguasai materi yang diajarkan di sekolah.

Sadar akan hal tersebut, UPT Bahasa Universitas Tanjungpura menjawab tantangan ini dengan menghadirkan sebuah program pendampingan siswa yang bernama Program Adik Dosen. Program Adik Dosen sendiri nantinya akan menyediakan layanan tutorial untuk beberapa mata pelajaran di sekolah yang dianggap cukup sulit. Untuk membatasi pertemuan secara fisik, program ini akan diberikan secara online dan hybrid. Program ini akan memberikan akses pendampingan bagi anak-anak sehingga diharapkan dapat membantu para orang tua yang memiliki kesibukan di luar rumah. Selain itu, program ini dirancang dalam bentuk kelompok belajar dengan jumlah peserta didik yang kecil. Selama ini, sistem belajar kolektif dengan banyak peserta didik dalam satu rombongan belajar besar seringkali membuat siswa kesulitan dalam memahami pelajaran di sekolah (Alsalihi, 2020). Hal ini menjadi salah satu problematika bagi orang tua yang mengeluhkan turunnya prestasi putra-putri mereka, terutama saat menghadapi ujian kenaikan kelas maupun kelulusan. Sebab itu, dalam program ini, jumlah peserta didik dibatasi antara 7-10 orang saja untuk menjaga agar peserta didik tetap fokus.

Untuk mencapai tujuan-tujuan tersebut, segala hal harus dipersiapkan dengan matang, terutama kualitas dari pendidik hingga kesiapan mereka dalam mengajar di kelas yang sesungguhnya. Oleh sebab itu, kegiatan pertama yang dilakukan dalam program PKM tahun ini adalah memberikan pelatihan dan pendampingan kepada para tutor Adik Dosen sebelum mereka terjun langsung ke lapangan. Menurut Konig, Jager-Biela, dan Glutsch (2020), guru di era 
seperti sekarang harus memiliki kompetensi mengajar secara digital dan kesempatan untuk mempejarai perangkat-perangkat digital ini untuk pemanfaatan belajar peserta didik. Kedua hal ini jelas sulit dimiliki jika para siswa didampingi oleh saudara dan kerabat mereka. Pendamping yang berasal dari keluarga kemungkinan akan menemui kesulitan dan tidak dapat mengantisipasi masalah yang muncul selama pembelajaran daring. Sebab itu, program Adik Dosen hadir untuk membantu para orang tua ini dengan menyediakan tenaga pengajar pendamping yang tidak hanya menguasai perangkat-perangkat digital, tetapi juga mendapat pelatihan yang cukup untuk memanfaatkan perangkat ini dalam mendampingi pembelajaran peserta didik.

Pelatihan PKM ini bertujuan untuk membimbing para tutor Adik Dosen dalam mempersiapkan silabus, mengelola kelas secara online, hingga mengevaluasi peserta didik. Layanan ini diyakini dapat mendukung proses belajar mengajar dikelas sehingga diharapkan dapat mengingkatkan kemampuan peserta didik secara lebih maksimal.

Selanjutnya, para tutor Adik Dosen dosen akan diberikan kesempatan untuk mengajar di sebuah kelas pilot dalam sebuah periode magang. Manfaat dari kelas ini adalah untuk memberikan waktu para tutor menyesuaikan manajemen kelas online sekaligus menjadi bahan evaluasi untuk para Dosen pelaksana PKM. Harapannya, setelah melalui proses pelatihan, pendampingan, dan praktik lapangan ini, Adik Dosen mampu menghasilkan tutor dengan keahlian yang cukup yang memiliki bidang yang sesuai dengan kebutuhan siswa.

Tim PKM UPT Bahasa tahun ini akan mengoptimalkan mahasiswa penerima beasiswa Untan seperti mahasiswa Comdev \& Outreaching. Pemberdayaan mahasiswa-mahasiswa dalam program Adik Dosen ini selaras dengan semangat Kampus Merdeka yang saat ini dicanangkan oleh Kementerian Pendidikan dan Kebudayaan. Melalui program ini, mahasiswa Untan mempunyai wadah untuk menerapkan ilmu yang diperoleh di kelas dengan cara menjadi tutor bagi pelajar-pelajar di sekolah. Selanjutnya, melalui pendampingan langsung oleh Dosen dan pengalaman menjadi tutor, mahasiswa Untan dapat mengembangkan diri secara profesional dan merasakan atmosfer dunia kerja yang sesungguhnya.

\section{METODE}

Poin sebelumnya menyinggung permasalahan yang umum dijumpai orang tua pada saat menemani putra-putri mereka belajar secara daring. Kesibukan mereka sehari-hari dan penguasaan materi yang minim menjadi keluhan yang sering diungkapkan orang tua. Akibatnya, hasil yang diterima anak-anak mereka menjadi tidak maksimal, seperti ketika mereka belajar secara tatap muka. Oleh sebab itu, dibutuhkan tenaga pengajar yang dapat membantu orang tua mendampingi anak-anak mereka selama belajar daring. Namun demikian, para pengajar ini tentu harus memiliki kualifikasi yang baik dan kompeten di bidang teknologi karena pembelajaran di era pandemi mensyaratkan penggunaan perangkat digital dengan porsi yang jauh lebih banyak.

Tim PKM UPT Bahasa Untan kemudian hadir dengan menawarkan sebuah program Adik Dosen. Program ini memberikan solusi pengajar atau tutor yang siap mendampingi anak untuk belajar selama jam sekolah ataupun diluar jam sekolah. Para tutor ini memiliki latar belakang yang sesuai dengan materi yang anak-anak dapatkan di sekolah dan merupakan mahasiswamahasiswa terbaik yang diseleksi dari program Comdev-Outreaching Untan. Untuk lebih meningkatkan kualitas mereka, para tutor ini juga akan menerima pelatihan pemanfaatan perangkat digital guna menunjang kompetensi mereka dalam mengajar. Pelatihan mereka dapatkan dalam bentuk teori (seminar) secara tatap muka. Erpidawati dan Novelti (2021) menyatakan bahwa seminar bertujuan untuk membahas beberapa isu relevan dan mencari jalan keluarnya. Oleh sebab itu, materi pelatihan (seminar) untuk para tutor ini diarahkan pada isuisu yang sering dialami guru pada saat mengajar online dan bagaimana cara mengantisipasinya. 
Setelah itu, mereka akan mengikuti sesi praktik mengajar (magang) secara daring selama 1 bulan. Menurut Nghia dan Tai (2017), proses praktik mengajar (magang) sangat bagus bagi perkembangan identitas para tutor sebagai pengajar. Pada saat magang, mereka akan mengalami proses negosiasi atas apa yang selama ini mereka dapatkan secara teori di kelas dengan apa yang terjadi di lapangan. Responden dari Nghia dan Tai, misalnya, awalnya berfikir bahwa semua anak-anak di level sekolah dasar itu menyenangkan. Begitu pula dengan guruguru yang ada di level tersebut. Ternyata, setelah mengikuti magang, mereka melihat bahwa banyak juga anak-anak yang tidak kooperatif dan guru-guru senior yang tidak ramah. Selain itu, proses magang juga memberikan mereka kesempatan untuk belajar menyesuaikan strategi mengajar. Mereka jadi menyadari bahwa tidak semua strategi mengajar yang sudah direncanakan bisa berjalan dengan baik. Mereka harus menyesuaikan dengan situasi keadaan sesungguhnya yang terjadi di kelas.

Kesimpulannya, dua model pelatihan dan pendampingan (magang) di atas diharapkan membantu para tutor menjadi lebih siap dan terampil. Hal ini juga sesuai dengan apa yang sebelumnya disarankan oleh Konig, Jager-Biela, dan Glutsch (2020) untuk para guru di Jerman. Pelatihan ini kemudian akan diberikan oleh tim PKM dari UPT Bahasa Universitas Tanjungpura. Mahasiswa peserta program PKM Adik Dosen tahun ini berjumlah 17 orang yang terbagi dalam 3 mata pelajaran, yaitu: Bahasa Inggris, Matematika, dan Fisika.

\section{HASIL DAN PEMBAHASAN}

Pelatihan dan pendampingan untuk tutor Adik Dosen ini dilaksanakan selama kurang lebih 4 bulan. Kegitan ini diawali dengan sesi pelatihan dalam bentuk seminar sebanyak 6 pertemuan yang bertujuan untuk memperdalam pemahaman teori para tutor dalam mengajar secara daring. Kegiatan ini penting untuk menitikberatkan perpindahan paradigma dan gaya mengajar yang saat ini sedang dialami oleh para guru hampir di seluruh dunia. Di sesi ini peserta akan mendapat pengetahuan teknik merancang dan mengelola kelas secara daring. Peserta juga menerima materi tentang cara berkomunikasi dengan siswa dan orang tua pada saat berada di dunia maya. Peserta juga memiliki kesempatan untuk melakukan sesi micro teaching sebelum mereka terjun ke tahap yang sebenarnya.

Setelah sesi ini selesai, para peserta akan melaksanakan program magang selama 1 bulan dimana mereka akan hadir di kelas sebanyak 2 kali sebagai pengajar dan sisanya sebagai pengamat untuk menyaksikan dan belajar bagaimana rekan sejawat mereka mengajar. Sesi magang ini dilakukan sebanyak 2 kali seminggu selama satu bulan.

\section{Tahap 1 (Sesi Pelatihan Tutor Adik Dosen)}

Tahap 1 pelatihan berlangsung dari tanggal 23 April - 3 Mei 2021 di UPT Bahasa Untan. Setiap harinya, para tutor Adik Dosen menerima pelatihan intensif selama 2 jam. Agenda pertama dimulai dengan pemaparan program Adik Dosen yang yang disampaikan oleh ketua tim PKM, Stella Prancisca. Beliau menjelaskan secara rinci teknis program dan pelatihan yang diterima para tutor dalam bebera bulan ke depan. Pada pertemuan berikutnya, materi disampaikan oleh Kepala Badan Pengelola dan Pengembangan Usaha (BPPU) untan yakni Dr. Irfani Hendri. Beliau memberikan motivasi yang memicu semangat para tutor adik dosen dalam mengikuti program ini. Dr. Irfani menyampaikan bahwa program ini selaras dengan program Kampus Merdeka dimana mahasiswa bisa menyalurkan ilmu yang mereka dapatkan di bangku kuliah di dunia kerja yang sesungguhnya. Di hari ketiga, para peserta pelatihan mendapatkan materi gaya berkomunikasi guru di era sekarang. Materi ini disampaikan oleh pakar Ilmu Komunikasi Ibu Dewi Utami, M.S. Strategi berkomunikasi ini penting untuk diketahui para tutor Adik Dosen mengingat sekarang mereka menghadapi situasi pembelajaran yang sangat baru dimana seluruh proses komunikasi dilaksanakan secara virtual. 


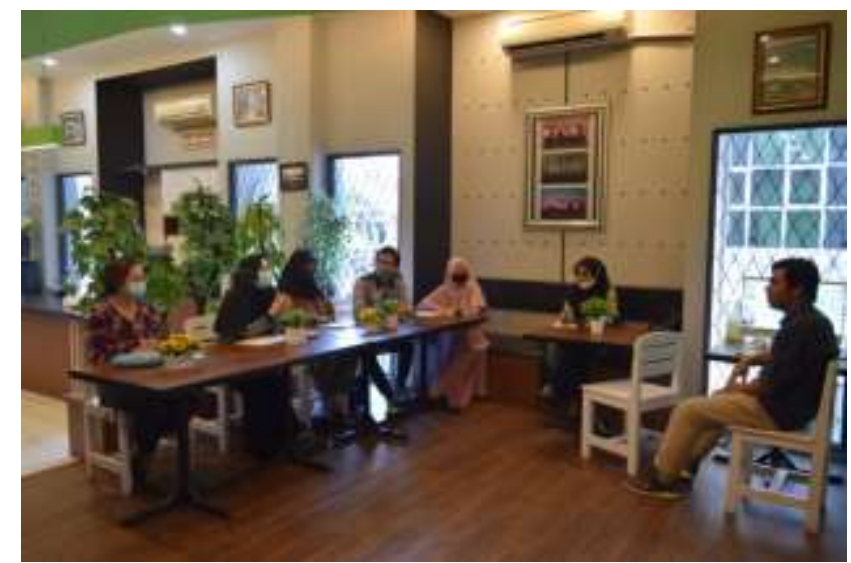

Gambar 1 Peserta seminar (tutor Adik Dosen) berdiskusi dengan pemateri

Pada pertemuan ke 4, para tutor Adik Dosen dilatih untuk meningkatkan kemampuan mereka dalam memanfaatkan perangkat digital. Dari sekian banyak sumber belajar digital yang tersedia di internet, mereka berlatih memilih perangkat atau sumber belajar dan merancang rencana pembelajaran yang sesuai dengan karakteristik kelas dan tujuan pembelajaran mereka. Mereka juga belajar menggunakan platform yang umum digunakan seperti Google Classroom dan Zoom dan cara mengantisipasi permasalahan yang kemungkinan muncul. Pertemuan ini dimentori oleh tiga pemateri berbeda untuk menyesuaikan dengan mata pelajaran yang tersedia, Dr. Dwiria Wahyuni pada pelajaran Fisika, Nurainul Miftahul Huda, M.Si untuk pelajaran Matematika, dan Muhammad Ainur Rizqi, MA untuk Bahasa Inggris. Sesi ini dilanjutkan dihari berikutnya dimana para tutor mendapatkan materi seputar ilmu kependidikan terutama dalam peran mereka sebagai guru di era revolusi industri 4.0. Materi ini disampaikan oleh pakar pendidikan Dr. Ikhsanudin dari FKIP Untan. Pertemuan terakhir meliputi sesi praktik di mana tutor Adik Dosen berlatih untuk memberikan materi pelajaran dalam format micro teaching. Di sesi ini para peserta mendapatkan banyak masukan terkait penampilan mereka yang bisa mereka gunakan nanti pada saat sesi mengajar yang sebenarnya.

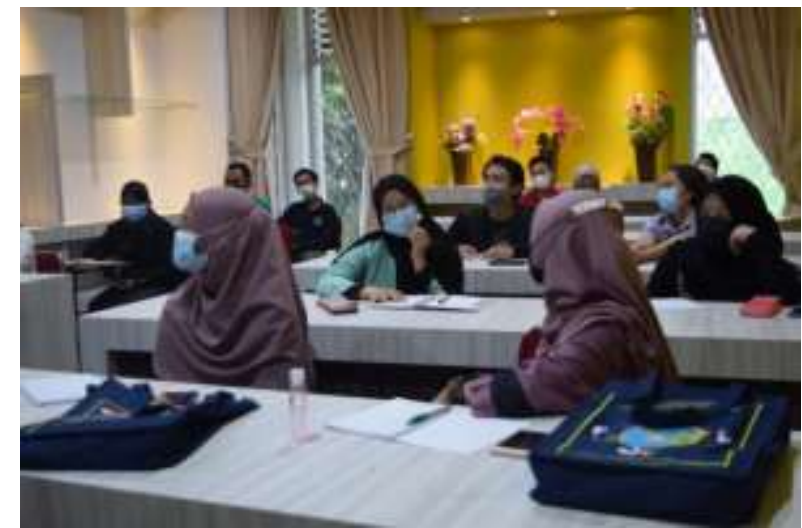

Gambar 2 Peserta seminar (tutor Adik Dosen) menyimak penjelasan dari pemateri

\section{Tahap 2 (Sesi Pendampingan Tutor Adik Dosen)}

Setelah mendapatkan pelatihan di kegiatan sebelumnya, para tutor adik dosen memiliki waktu kurang lebih 1 bulan (Mei-Juni) untuk menyusun materi yang akan disampaikan di kelas. Proses penyusunan ini melibatkan beberapa kali pertemuan yang didamping oleh Tim Pelaksana PKM. Tim Pelaksana PKM memberikan masukan-masukan yang sesuai dengan bidang studi masing-masing. Setelah itu, program magang dimulai pada tanggal 10 Juni hingga 12 Juli 2021. Para tutor yang terdiri dari 17 orang akan mengajar di kelas pilot yang berisi peserta didik yang terdiri dari salah satu dari 3 jenjang yaitu; SD, SMP, dan SMA. Setiap tutor berlatih mengaplikasikan apa yang sudah di dapat dari pelatihan sebelumnya. Proses ini dilaksanakan 
secara daring dua kali per minggu dan berlangsung selama 1,5 jam per pertemuan. Setiap tutor mendapat kesempatan dua kali untuk mengajar dan sisanya berperan sebagai pengamat dimana mereka bisa memperhatikan gaya mengajar teman-teman mereka. Tujuannya adalah untuk memperkaya variasi mengajar dan mengurangi kemungkinan permasalahan yang timbul di kelas lain.

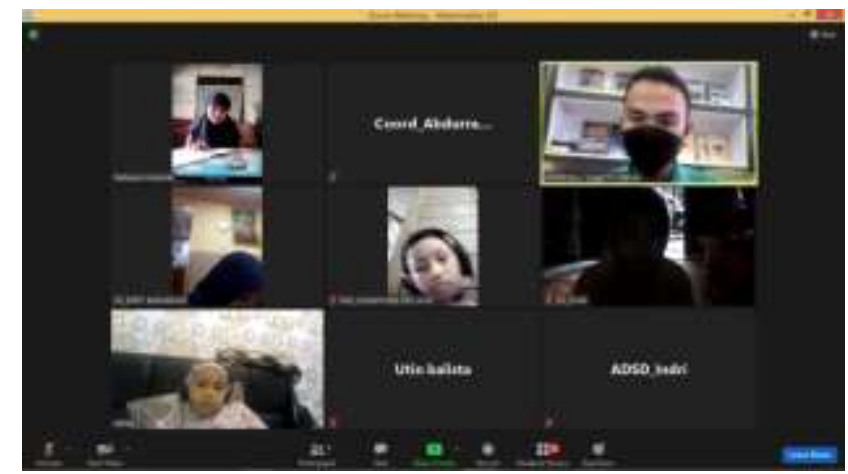

Gambar 3 Proses praktik mengajar (magang) tutor pendamping

Para tutor menanggapi sesi magang secara bervariasi. Karena ini merupakan pengalaman pertama bagi beberapa tutor untuk mengajar secara online, mereka merasa agak cukup gugup di awal-awal sesi. Terutama ketika mereka mendapatkan masalah-masalah kecil seperti microphone siswa yang aktif dan kesulitan untuk membagikan gambar, video, atau suara. Meskipun ini sudah mereka dapatkan di sesi pelatihan, tapi beberapa tutor tetap merasa kesusahan pada saat praktik langsung. Salah satu sebabnya kemungkinan karena pada saat magang para tutor harus membagi konsentrasi mereka dalam menggunakan perangkat digital dan mengelola kelas pada waktu yang bersamaan. Akibatnya, mereka menjadi sedikit panik. Namun demikian, seiring berjalannya waktu para tutor mulai terbiasa. Selain itu, pengalaman yang mereka lihat dari teman-teman sebelumnya membuat tutor yang tampil di pertemuan selanjutnya menjadi lebih siap.

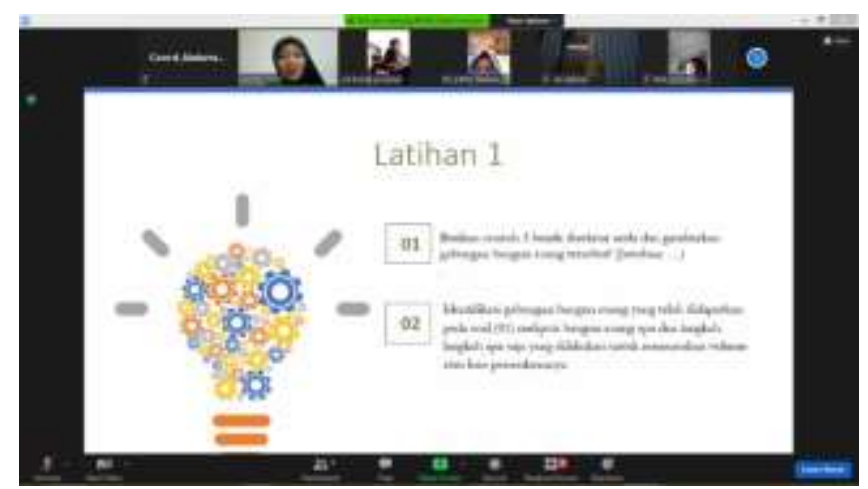

Gambar 4 Contoh latihan yang tampil di layar zoom

\section{KESIMPULAN}

Munculnya pandemi Covid-19 di Indonesia pada tahun 2020 memaksa semua orang keluar dari zona nyaman, termasuk dunia pendidikan. Meskipun para pakar sejak lama sepakat akan manfaat pembelajar online di kelas, tidak ada yang menyangka bahwa pergeseran itu akan terjadi dengan begitu cepat dan mendadak. Akibatnya, banyak pihak yang tidak siap dan merasa kesulitan. Salah satunya dari pihak orang tua. Dengan kesibukanpara orang tua bekerja, model pembelajaran secara daring dari rumah menjadi sumber keluhan mereka. Waktu yang tersita untuk bekerja dan kurangnya penguasaan materi dan kreatifitas pada saat mendampingi anak mereka menjadi keluhan yang paling banyak diungkapkan. 
Program PKM UPT Bahasa Universitas kemudian hadir untuk menawarkan program Adik Dosen sebagai solusi dengan menyediakan tenaga pengajar yang dapat mendampingi putra-putri para orang tua ini. Dengan keahlian mereka dalam bidang digital dan pelatihan yang telah mereka terima, para tutor ini dinilai cukup kapabel untuk menjadi tutor pendamping. Tentunya, agar kualitas para tutor ini semakin baik, UPT Bahasa terlebih dahulu memberikan sebuah pelatihan dan pendampingan yang bertujuan untuk mempersiapkan mereka menjadi pendamping secara daring.

17 mahasiswa yang berasal dari Comdev \& Outreaching Untan berpartisipasi dalam program ini untuk berperan sebagai tutor pendamping di program Adik Dosen. Sebelum turun mengajar, mereka terlebih dahulu mendapatkan pelatihan intensif selama 6 pertemuan untuk mengasah kemampuan mereka dalam menguasai materi, dasar-dasar pengajaran, serta pengembangan bahan ajar dengan memanfaatkan sumber belajar digital. Setelah itu, mereka melaksanakan praktik mengajar selama 1 bulan secara daring.

Terakhir, program PKM ini memberikan sebuah rekomendasi untuk kegiatan serupa yang mungkin akan diadakan di masa mendatang. Mengingat kondisi pandemi mulai menunjukkan tanda perbaikan dan orang-orang mulai terbiasa menerapkan protokol kesehatan, ada kemungkinan bahwa pelaksanaan kelas di masa depan akan hybrid atau kombinasi daring dan luring. Oleh sebab itu, kami merekomendasikan untuk memberikan pelatihan yang mengkombinasikan dua mode pembelajaran ini.

\section{UCAPAN TERIMA KASIH}

Penulis mengucapkan terima kasih yang setinggi-tingginya kepada Universitas Tanjungpura atas dukungan yang diberikan dalam bentuk kemudahan akses dan bantuan finansial.

\section{DAFTAR PUSTAKA}

Alsalihi, H. D. A. (2020). Main Difficulties Faced by EFL Students in Language Learning. Journal of the College of Education for Women, 31(2), 19-34.

Dhawan, S. (2020). Online Learning: A Panacea in the Time of COVID-19 Crisis. Journal of Educational Technology Systems, 49(1), 5-22.

Epidawati \& Novelti. (2021). Pelatihan Pemanfaatan Teknologi Google Drive dan Blogs bagi Pengawas Sekolah Dasar. DINAMISIA: Jurnal Pengabdian Kepada Masyarakat. 5(2), 330-334.

Herliandry, L. D., Nurhasanah, N., Suban, M. E., \& Kuswanto, H. (2020). Pembelajaran pada Masa Pandemi Covid-19. JTP-Jurnal Teknologi Pendidikan, 22(1), 65-70.

König, J., Jäger-Biela, D. J., \& Glutsch, N. (2020). Adapting to Online Teaching during COVID-19 School Closure: Teacher Education And Teacher Competence Effects among Early Career Teachers in Germany. European Journal of Teacher Education, 43(4), 608-622.

Mukhtar, K., Javed, K., Arooj, M., \& Sethi, A. (2020). Advantages, Limitations and Recommendations for Online Learning during COVID-19 Pandemic Era. Pakistan journal of medical sciences, 36(COVID19-S4), S27.

Nghia, T.L.H., \& Tai, H.N. (2020). Preservice Teachers' Identity Development during the Teaching Internship. Australian Journal of Teacher Education. 42(8), 1-15.

Nuryatin, S. (2020). Adaptasi Metode Pembelajaran Melalui E-Learning Untuk Menghadapi Era New Normal. https://doi.org/10.31219/osf.io/nd72p.

Rahmania, S., Wijayanti, R., \& Hakim, S. L. (2021). Strategi Orang Tua Dalam Pendampingan Belajar Anak Selama Pandemi Covid-19. Literasi: Jurnal Kajian Keislaman Multi-Perspektif, 1(1), 99-110.

Sun, L., Tang, Y., \& Zuo, W. (2020). Coronavirus Pushes Education Online. Nature Materials, 19(6), 687-687. 